\title{
EFFECT OF FABA BEAN SEED SPROUTING USING SALINE WATER ON ITS ANTIOXIDANT PROPERTIES
}

\section{Hagezy $^{1 \star}$ A.M., Nashwa² A. Abo El-Azam, El-Gammal ${ }^{1}$ M.H.A. and Abdalleh' ${ }^{2}$ M.M.F.}

1- Regional Central for Food and Feed, Agric. Res. Center, Giza, Egypt

2- Horticulture Dept., Fac. of Agric., Ain Shams Univ., P.O. Box 68, Hadayek Shubra 11241, Cairo, Egypt

${ }^{*}$ Corresponding author: www.am7626019@gamil.com

\section{ABSTRACT}

Legumes play a fundamental role in human nutrition in many countries. Germination is considered as one of the most effective processes to improve the quality of legumes. Faba bean seeds have been chosen for this study, to do a comparative study on the chemical analysis and phytochemical contents of the faba bean seeds and their germinated samples using tap and saline water was studied. The antioxidant activity (total antioxidants, phenols and flavonoids) comparison of the seed and the selected sprouted samples was, also, extended.

Vitamins, phenols, total flavonoids and other important compounds, that might be considered beneficial as antioxidants, often dramatically change during the course of germination. The obtained data of the current study revealed, through measuring sprout characters, that $1000 \mathrm{ppm} \mathrm{NaCl}$ was the appropriate concentration with respect to performance of the sprouting of Faba bean.

It was, also, found that there was a slight increasing in protein, amino-acids and some minerals in tap and saline water sprouted samples. A marked increasing in antioxidant activity, total phenols and total flavonoids in tap water and saline water sprouts was also detected. It could be concluded that germination process increases the nutritive value of the seeds and is a good way to enhance the antioxidant properties of legume seeds. Consequently, germination process could be used as a source of natural antioxidants in functional foods and could be considered as an important step towards the future evolvement of value-added foods and which can be used in the development of novel food products with beneficial effects on human's health.

Keywords: Sprouting; Saline water; Characteristics of faba bean seeds

\section{INTRODUCTION}

Legumes are one of the most essential sources of food in the world. Cooking is usually done before using of legumes in human diet. This improves the protein quality by destruction or inactivation of the heat-labile antinutritional factors. However, cooking causes losses in soluble solids, especially vitamins and minerals. Increasing the time and temperature of processing has been reported to reduce the nutritive values and available lysine of legumes (Vijayakumari et al 1998). However, antinutritional factors limit the food applications of legumes. Germination, also, enhances the nutritive value of legumes by inducing the formation of enzymes that eliminate or reduce the antinutritional and indigestible factors in legumes (Bau et al 1997).

Some biotechnological processes and methods such as germination are considered simple and economical to improve the nutritive values of legumes by causing desirable change in the nutrient availability, texture and organoleptic characteristics. Extended breakdown of seed-storage compounds and synthesis of structural proteins and other cell components occur during the germination. Secondary compounds and many of which are considered beneficial as antioxidants, often dramatically change during the germination (Kuo et al 2004). It is known that the germination 
process mostly improves the nutritional quality of legumes, not only by the reduction of anti-nutritive compounds but, also, by increasing the levels of free amino acids, available carbohydrates, dietary fiber and other components, as well as increasing the functionality of the seeds due to the dependent increase in the bioactive compounds (LopezAmoros et al 2006).

Food legumes have been playing very fundamental role in the human diet for a long time. In recent years, consumer interest in healthy food has increased. Dieticians recommend utilization of legume plants as a worthy source of proteins, vitamins, minerals and various bioactive components. Increasing popular additions to dishes such as sprouts plants, including adzuki beans, are spreading from Far East. The sprouts are excellent examples of 'functional foods' defined as an agent to lower the risk of various diseases (Randhir et al 2004). Legume sprouts are rich in amino acids, macro and microelements and a variety of vitamins. They are recommended for people with ailments of the pancreas and kidneys. The valuable effects are especially attributed to phytochemicals such as phenolic compounds. During the germination of seeds, nutrients under influence of moisture, temperature, and primarily enzymes action are transformed into compounds facilely and quickly absorbed by the body. The raise content of bioactive compounds causes that consumption of sprouts strengthens body's immunity ( $\mathbf{L i}$ et al 2011).

Bioactive compounds and antioxidant activity of germinated mung bean and soybean sprouts were investigated by (Xue et al 2016) to find out the effect of germination and the optimum germination time. They found vitamin C gradually increased from zero. Compared to seeds, water soluble protein and total flavonoid content showed a trend of sustained growth.

Faba bean sprouts contain more polyphenol than the bean itself. Antioxidant screening program has shown that fava bean sprouts also possess a higher antioxidant activity than other commercially available sprouts and mature beans. They could therefore be useful in the diet as an attractive and palatable source of antioxidants to help maintain human health (Okumura et al 2016).

The objectives of this study were first to estimate the effect of different concentration of saline water $(\mathrm{NaCl})$ Comparing with Tap water on Faba been seeds germination. Second, compare the chemical analysis and phytochemical contents of the selected dry seeds and their germinated sam- ples. Beside to, compare the antioxidant activity (as well as the phenols and flavonoids contents) of the selected sprouted samples.

\section{MATERIALS AND METHODS}

The current study was carried out at Horticulture Department, Faculty of Agriculture, Ain Shams University, Cairo and the Regional Center for Food and Feed (RCFF), Agricultural Research Center (ARC), Giza with in the 2016-2017 season.

Faba bean seeds (Sakha 4 variety) were was obtained from the Crop Institute, Agricultural Research Centre, Giza, Egypt. 50 gram of beans were weighted after washing and the bad seeds were excluded, then were put eed in a plastic jar with $300 \mathrm{ml}$ of Tap water as a control sample.

Different concentrations (1000, 2000, 3000, $4000 \mathrm{ppm}$ ) of saline water $(\mathrm{NaCl})$ for $18 \mathrm{hr}$ were used as a soaking media in the tested samples instead of top water in the control sample. The get rid of socking water and wash them every $8 \mathrm{hr}$. All samples were left to germinated up to 2 days.

The sprouted seeds were collected for measuring sprout characters after 2 Days. According to the best results of measuring characters, the tested samples were samples were ground in the laboratory by a miller mill and the grounded seeds wer stored at $5^{\circ} \pm 1^{\circ} \mathrm{C}$ until analysis and except for vitamins determination where it must be done on fresh samples.

The data were statistically analyzed by analysis of variance using completely randomized design and least significant difference (LSD) at 0.05 levels according to the method described by (Snedecor and Cochran, 1980).

\section{Chemical analysis}

\section{Proximate analysis}

Total crude protein, fats, fiber, moisture, and ash were analyzed according to (AOAC 2012). Total carbohydrates were determined by differences (Chinma \& Lgyor, 2007).

\section{Minerals determination}

All mineral: Iron, Magnesium, Copper, Zinc, Selenium, Sodium, Potassium, Manganese, Calcium and phosphorus were analyzed by ICP optima 2000 DV Perkin Elmer according to the method described in the (AOAC 2012). 


\section{Amino acids analysis}

Amino acids determination was performed according to (AOAC 2012). The instrument used for analysis was Eppendorf LC 3000.EZ Chrom.

\section{Determination of vitamins C, A, E contents}

All samples were analyzed according to Ministry of Health Institute of food Chemistry and Nutriton Danish official. (AOAC, 2012).

\section{Determination of total antioxidant activity}

The antioxidant activity was expressed as ascorbic acid. The absorbance of samples was measured at $695 \mathrm{~nm}$ using a spectrophotometer according to the procedure described by (Prieto et al 1999). All tests were performed in triplicate and means were calculated.

\section{Phytochemical constituents}

Samples were extracted using anhydrous ethyl alchol according to (Santana et al 2013). $1 \mu \mathrm{L}$ of sub sequent filtrate was injected into GC/MS for analysis.(Agilent 7000 Triple quad)

The analysis was carried out using a GC (Agilent Technologies 7890A) interfaced with a massselective detector (MSD, Agilent 7000 Triple Quad) equipped with Agilent HP-5ms capillary column. The carrier gas was helium with the linear velocity of $1 \mathrm{ml} / \mathrm{min}$. The injector and detector temperatures were $200^{\circ} \mathrm{C}$ and $250^{\circ} \mathrm{C}$, respectively. Volume injected $1 \mu \mathrm{l}$ of the sample. The MS operating parameters were as follows: ionization potential 70 $\mathrm{eV}$, interface temperature $250^{\circ} \mathrm{C}$, and acquisition mass range 50-600.

\section{RESULTS AND DISCUSSION}

\section{Effect of $\mathrm{NaCl}$ concentrations on sprouting characters of Faba bean seeds}

Table (1) showed Faba bean sprouts (2 days old etiolated) length, fresh and raw seeds. Mean of sprout length varied between 0.79 and $1.09 \mathrm{~cm}$ at various $\mathrm{NaCl}$ concentrations. The longest length was observed in the control and in 1000 ppm $\mathrm{NaCl}$.

The same Table showed that by increasing $\mathrm{NaCl}$ concentration, sprout length decreased to 80 , 79 and $67 \%$ at 2000, 3000 and 4000 ppm NaCl, respectively with no significant decrement at 1000 ppm $\mathrm{NaCl}$ compared with control.
Fresh and dry weight in Fba bean sprouts gave the highest value and had no significant in 1000 ppm NaCl concentrations, in case of fresh weight, compared with control (tap water). These result reveres that $1000 \mathrm{ppm} \mathrm{NaCl}$ is the appropriate concentration for performance the sprouting of Faba bean and was select for making the chemical analysis and phytochemical Contents estimation.

\section{Proximate analysis result}

Table (2) show the results of proximate analysis of Faba bean seeds and its sprout using tap water, saline water (1000 ppm $\mathrm{NaCl})$. The protein content of Faba bean ranged from 20 to $41 \%$, values which depend on the variety. Faba bean seeds contain $51 \%$ to $68 \%$ of carbohydrate in total, the major proportion of which is constituted by starch (41-53\%).

It was found that there was not any noticable change in proximate analysis results except for protein which has shown an increasing in sprouts samples in both treatments tap and saline water. Assuming that increasing was due to synthesis of enzyme proteins activities (for example, proteases) by germinating or a compositional change following the degradation of other constituents as imposed by (Bau et al 1997), (Nonogaki et al 2010). Where it was noted that, protein synthesis occurred during imbibition and that hormonal changes play an essential important role in achieving the completion of germination.

\section{Minerals results}

Minerals contents in samples are shown in Table (3). There was some increasing in $\mathrm{Ca}, \mathrm{P}, \mathrm{Mg}$ and $\mathrm{Zn}$ contents in tap and saline water sprouts. Samples compared with the raw seeds. Na content was highly increased especially in saline water sprouts which attributed to the $\mathrm{NaCl}$ concentration in the saline solution used for rinsing seeds during germination. This increasing in these elements was observed too in a study on green radish sprouts (Tahany, 2015). While Fe content was decreasing by sprouting as shown by (Yuwei and Weihua, 2014).

\section{Amino acids analysis}

Effect of sprouting the Faba bean seeds using tap water and saline water on Amino acids is shown in Table (4). Whereas there are wellbalanced between protein and amino acids, then slightly increase was found in the relative contents of both essential and non-essential amino acids 
Table 1. Effect of different concentrations of $\mathrm{NaCl}$ on 2 days old etiolated Faba bean sprouts characters

\begin{tabular}{|c|c|c|c|}
\hline Conc. of $\mathbf{N a C l}$ & $\begin{array}{c}\text { Sprout Length } \\
(\mathbf{c m})\end{array}$ & $\begin{array}{c}\text { Sprout dry weight } \\
(\mathbf{g m})\end{array}$ & $\begin{array}{c}\text { Sprout fresh weight } \\
(\mathbf{g m})\end{array}$ \\
\hline Tap water (control) & $1.18^{\mathrm{a}}$ & $0.7529^{\mathrm{c}}$ & $1.6840^{\mathrm{a}}$ \\
1000 & $1.09^{\mathrm{ab}}$ & $0.8177^{\mathrm{b}}$ & $1.6988^{\mathrm{a}}$ \\
2000 & $0.95^{\mathrm{bc}}$ & $0.8160^{\mathrm{a}}$ & $1.6693^{\mathrm{a}}$ \\
3000 & $0.94^{\mathrm{bc}}$ & $0.7886^{\mathrm{a}}$ & $1.5553^{\mathrm{b}}$ \\
4000 & $0.79^{\mathrm{c}}$ & $0.7789^{\mathrm{bc}}$ & $1.4738^{\mathrm{b}}$ \\
\hline LSD at 0.05 & 0.19723 & 0.0271 & 0.1020 \\
\hline
\end{tabular}

Table 2. Effect of sprouting of Faba bean seeds by tap and saline water on proximate analysis (as \% on wet Basis of dry weight)

\begin{tabular}{|c|c|c|c|}
\hline \multirow{2}{*}{ Analysis } & \multicolumn{3}{|c|}{ Sprouting faba bean } \\
\cline { 2 - 4 } & Raw Seed & With tap water & With saline water \\
\hline Crude protein & 21.30 & 23.50 & 25.00 \\
Fiber & 8.00 & 8.75 & 7.97 \\
Ash & 3.15 & 3.02 & 3.07 \\
Moisture & 6.96 & 7.21 & 6.72 \\
Fats & 1.54 & 1.58 & 1.6 \\
Carbohydrates & 59.05 & 55.94 & 55.64 \\
\hline
\end{tabular}

Table 3. Effect of Faba bean sprouting on minerals analysis (as \% on wet Basis of dry weight)

\begin{tabular}{|c|c|c|c|}
\hline \multirow{2}{*}{$\begin{array}{c}\text { Minerals } \\
(\mathbf{p p m})\end{array}$} & \multicolumn{3}{|c|}{ Sprouting Faba bean } \\
\cline { 2 - 4 } & Raw Seed & With tap water & With saline water \\
\hline $\mathrm{Ca}$ & 972.1 & 1290 & 1201 \\
$\mathrm{p}$ & 4665 & 4978 & 5187 \\
$\mathrm{Cu}$ & 13.49 & 15.34 & 13.79 \\
$\mathrm{Fe}$ & 55.25 & 41.34 & 42.60 \\
$\mathrm{Mg}$ & 1400 & 1537 & 1430 \\
$\mathrm{Mn}$ & 10.22 & 11.95 & 10.06 \\
$\mathrm{Zn}$ & 25.63 & 32.37 & 32.42 \\
$\mathrm{Se}$ & 2.750 & 3.415 & 2.761 \\
$\mathrm{Na}$ & 317.1 & 435.5 & 2510 \\
$\mathrm{~K}$ & 9987 & 9236 & 9146 \\
\hline
\end{tabular}




\section{Effect of Faba bean seed sprouting using saline water on its antioxidant properties}

Table 4. Effect of sprouting the Faba bean seeds using tap water and saline water ( $\mathrm{NaCl} 1000 \mathrm{ppm})$ on Amino acidscompared with dry seeds (g/100g dry weight Protein)

\begin{tabular}{|l|c|c|c|}
\hline \multicolumn{1}{|c|}{ Amino acid } & Raw Seed & Tap water & Saline water \\
\hline Aspartic acid & 10.89 & 9.32 & 9.56 \\
Therionine & 3.75 & 3.02 & 0.76 \\
Serine & 5.02 & 4.47 & 2.84 \\
Glutamic acid & 18.31 & 16.71 & 3.88 \\
Glycine & 4.18 & 3.32 & 14.80 \\
Alanine & 4.51 & 3.79 & 3.36 \\
Valine & 5.12 & 4.55 & 4.04 \\
Isoleucine & 4.22 & 3.70 & 4.16 \\
Leucine & 7.28 & 6.25 & 3.72 \\
Tyrosin & 3.90 & 3.45 & 6.20 \\
Phenylalanine & 4.69 & 4.00 & 3.44 \\
Histidine & 2.96 & 2.55 & 3.84 \\
Lysine & 6.95 & 6.08 & 2.40 \\
Arginine & 9.86 & 8.13 & 5.60 \\
Proline & 4.27 & 3.49 & 7.44 \\
Cysteine & 1.55 & 1.96 & 1.20 \\
Methionine & 1.08 & 0.98 & 0.72 \\
\hline
\end{tabular}

by germination process either by tap or saline water. Such observation was also reported by (Mostafa et al 1987) in their study on germination of soybean.

Chen and Thacke (1978) reported that during germination there is probably a turnover of proeins and amino acids With the balance between synhetic and dervative processes detemining the resultant pattern. The changes in amino acids content (increment insome and decrement in others) can be atttibuted to the release of amino groups from decrement amino acids to oxaloacetate in the shft from atorage protein to functional protein during the course of sprouring as reported before by (Dagnia et al 1992). Certain amino acids may be readily broken down than others and this is another potenial source of alternations in the protein pattern during germination (Rodriguez et al 2008).

Antioxidant activity, total phenols, total flavonoids and vitamins results of sprouting Faba bean were shown in Table (5). It was observed that sprouting showed an increasing in antioxidant activity total phenols and total flavonoids in both tap and saline water sprouted samples which imply that the ability of the components in sprouts (antioxidants) to scavenge free radicals increases after the germination process.

From Table (5) it is valuable to mention that vitamins $E$ and $C$ have increased in both tap and espicaly saline water. This is consistent with (Kavas and Nehir (1992), who noticed that germination significantly increased the content of ascorbic acid of the white beans, black beans and pigeon beans. Whereas the ascorbic acid increment in soybeans Brag variety germinated for four days was $\mathbf{9 0 \%}$ (Ahmad and Pathak, 2000). Therefore, the germinated legume seeds can be considered premium source of ascorbic acid.

This reverses that sprouts of Faba bean either from tap water or saline water are valuable source of antioxidants which can be used in the development of innovative food products. 
Table 5. Effect of sprouting Faba bean on Antioxidant Activity, total phenols, total flavonoids and vitamins compared with raw seeds.

\begin{tabular}{|l|c|c|c|}
\hline \multirow{2}{*}{\multicolumn{1}{|c|}{ Analysis }} & \multicolumn{3}{c|}{ Sprouting faba bean } \\
\cline { 2 - 4 } & Raw Seeds & Tap water & $\begin{array}{c}\text { Saline water } \\
\text { (NaCl) }\end{array}$ \\
\hline Activity Antioxidant mgl100g & 303.88 & 315.44 & 379.38 \\
total phenols (ppm) & 1717 & 2332.5 & 2387 \\
total flavonoids ppm ) & 17.10 & 275.10 & 244.8 \\
Vitamin A(IU) & $\mathrm{ND}$ & $\mathrm{ND}$ & $\mathrm{ND}$ \\
Vitamin E (IU) & 0.28 & 0.36 & 0.95 \\
Vitamin C (mg/100mg) & 0.0027 & 0.0034 & 0.0055 \\
\hline
\end{tabular}

\section{Phytochemical screening of Faba bean seed and sprouts}

The obtained Chromatogram for phytochemical screening compounds of Faba bean seed are shown in Fig. (1) and the chromatogram for phytochemical compounds of Faba bean sprouts using tap water and saline water are shown in Figs. (2 \& 3) respectively. Its whole recognized compounds are tabled in Table (6). It seems from the results in Table (6) that germination has a positive effect to present some phyto-compounds which weren't exist in the seed. Some of these compounds are phenols like as methyl 4-hydroxybenzoate, syringic acid and resorcinol. Others are terpienes like as: $\alpha$ Pinene, $\mathrm{Y}$-Terpinene, 4-Terpinenyl acetate, Geraniol, p-Cymen-7-ol and nopol. All these compounds were exist as a results of Faba bean germination.

Some compounds have been appeared in tap water sprouts and increased in saline water sprouts. Some of these compounds are phenols which has antioxidant activity as: homovanillic acid, 2,5-dihydroxybenzoic acid, 4-hydroxy-2- methoxybenzaldehyde, allo-Ocimene and vanylglycol. Other compounds are flavonoids which also has antioxidant activity as o-Cresol, $\alpha, \alpha^{\prime}-$ (propylenedinitrilo)di and Isoorientin.

Noteworthy that there were some compounds which appeared only in saline water sprouts owing to $\mathrm{NaCl}$ concentration. Some of these compounds are phenols as salicylic acid, cineole, 2-methoxy-5nitrophenol, methyl vanillate, levallorphan and propyl gallate. Others are terpienes as: mentha-2,8dien-1-ol, para, cis, $\beta$-terpinen, terpinen-4-ol, isopulegol, 3-bornanol, $\alpha$-terpinyl propionate, endoborneol, L- $\alpha$-terpineol, chamigrene, a-guaiene anda-cedrene.

It seems as shown by (Zoltek et al 2015) in their study on adzuki bean that sprouting reduces anti-nutritional factor and increases the bioavailability of macro, micronutrients and also affects phytochemical levels.

From the previous results it is cleared that germination has shown an increasing in the micronutrient, phyto-nutrient content of faba bean seeds, thus proving that there is clear increasing in the nutritive value of the seeds on sprouting. 


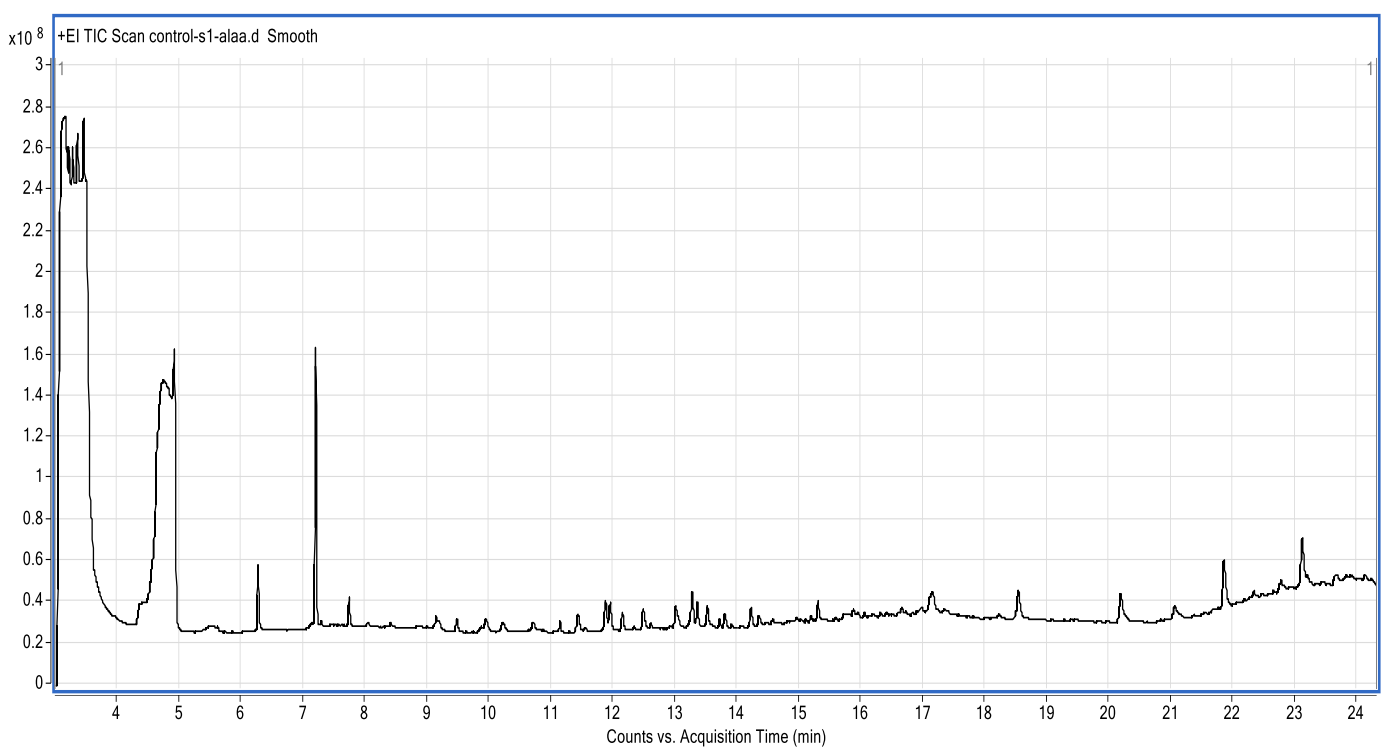

Fig. 1. GC/MS Chromatograph of seeds of Faba bean

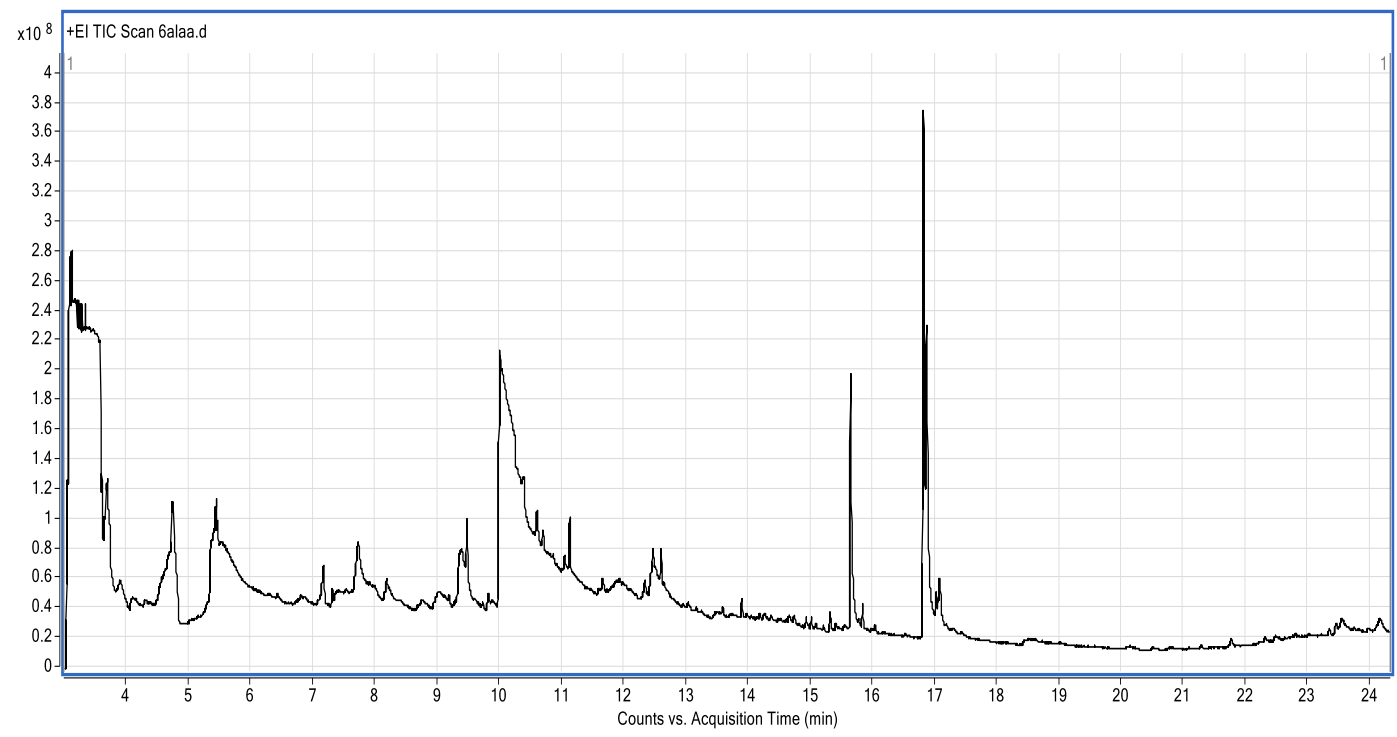

Fig. 2. GC/MS Chromatograph of sprouts Faba bean with tap water 


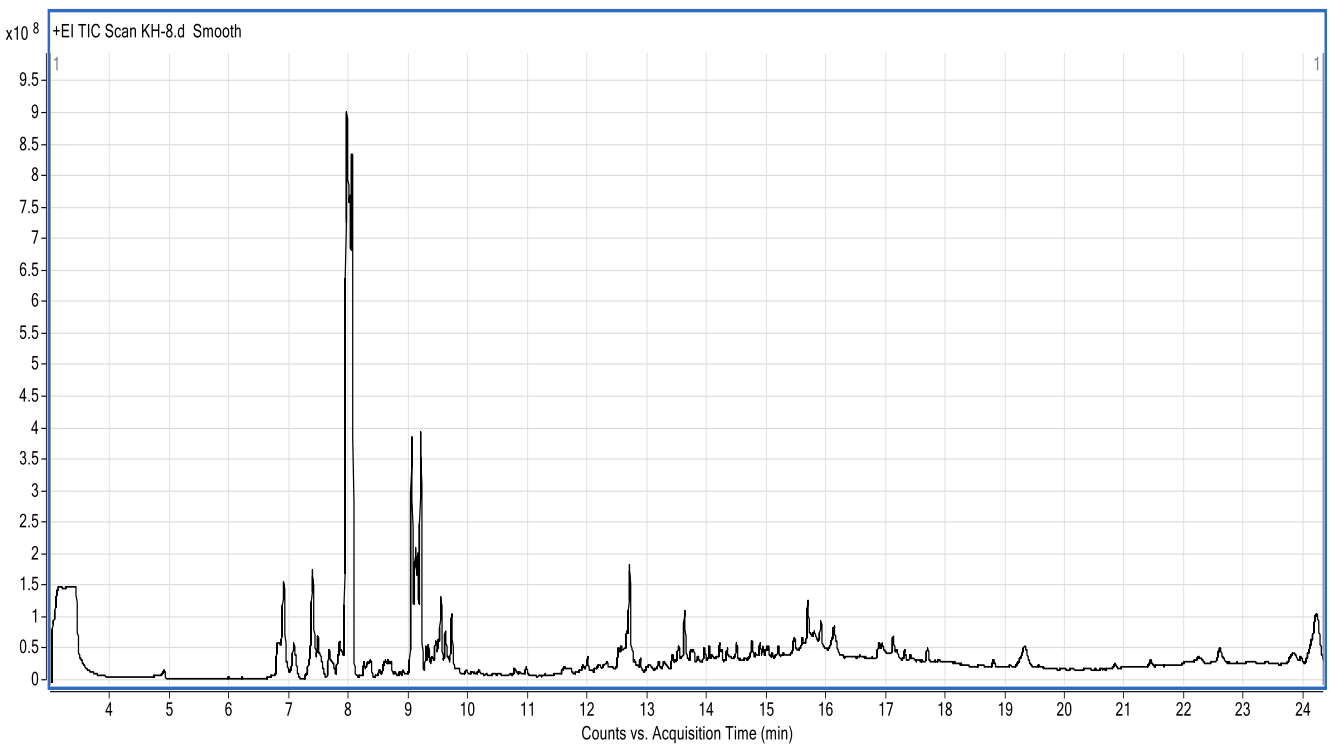

Fig. 3. GC/MS Chromatograph of sprouts Faba bean with saline water

Table 6. Phytochemical compounds identified in the ethanolic extract fractionation of Faba sprouts and seeds

\begin{tabular}{|c|c|l|c|c|c|}
\hline No & RT & Compound & $\begin{array}{c}\text { Raw } \\
\text { seeds }\end{array}$ & $\begin{array}{c}\text { Tap } \\
\text { water }\end{array}$ & $\begin{array}{c}\text { Saline } \\
\text { water }\end{array}$ \\
\hline 1 & 3.070 & Pivalic acid & 10.9 & 4.81 & 0.31 \\
2 & 3.247 & Sabinene & 20.72 & 11.09 & 5.18 \\
3 & 4.517 & 4-Methoxycinnamic acid & 20.17 & ---- & 0.16 \\
4 & 4.853 & Sinapyl alcohol & 2.96 & 4.07 & 0.26 \\
5 & 5.406 & dl-Allo-cystathionine & 0.70 & 4.09 & 0.21 \\
6 & 6.200 & Mentha-2,8-dien-1-ol, para, cis- & ----- & ------ & 0.15 \\
7 & 6.493 & Salicylic acid & ---- & ----- & 0.17 \\
8 & 6.673 & Esculetin & --- & 0.75 & 0.21 \\
9 & 6.814 & a-Pinene & --- & 0.48 & 1.04 \\
10 & 6.909 & Y-Terpinene & ---- & 0.73 & 2.66 \\
11 & 7.187 & a-Bisabolol & 2.56 & ----- & 1.08 \\
12 & 7.303 & Homovanillic acid & ---- & 0.71 & 2.72 \\
13 & 7.367 & 4-Terpinenyl acetate & ---- & 1.19 & 0.83 \\
14 & 7.413 & B-Terpinen & ---- & ---- & 1.18 \\
15 & 7.730 & 4',6-Dimethoxyaurone, trans- & 0.33 & 1.69 & 0.28 \\
16 & 7.877 & Cineole & ---- & ---- & 0.34 \\
17 & 7.947 & Terpinen-4-ol & ----- & ---- & 14.6 \\
18 & 8.048 & Isopulegol & ---- & 9.35 \\
19 & 8.057 & 3-Bornanol & ---- & 1.14 \\
\hline
\end{tabular}


Table 6. Cont.

\begin{tabular}{|c|c|c|c|c|c|}
\hline No & RT & Compound & $\begin{array}{c}\text { Raw } \\
\text { seeds }\end{array}$ & $\begin{array}{c}\text { Tap } \\
\text { water }\end{array}$ & $\begin{array}{l}\text { Saline } \\
\text { water }\end{array}$ \\
\hline 20 & 8.180 & o-Cresol, a,a'-(propylenedinitrilo)di- & ---- & 0.73 & 1.1 \\
\hline 21 & 8.637 & allo-Ocimene & ----- & 1.29 & 4.77 \\
\hline 22 & 9.086 & 2,5-Dihydroxybenzoic acid & ---- & 0.81 & 2.19 \\
\hline 23 & 9.111 & 2-Methoxy-5-nitrophenol & ---- & ---- & 4.37 \\
\hline 24 & 9.144 & 4-Hydroxy-2-methoxybenzaldehyde & ----- & 0.39 & 1.61 \\
\hline 25 & 9.129 & Methyl vanillate & ---- & ---- & 0.43 \\
\hline 26 & 9.199 & Geraniol & --- & 0.51 & 0.7 \\
\hline 27 & 9.291 & a-Terpinyl propionate & ---- & --- & 2.36 \\
\hline 28 & 9.364 & endo-Borneol & --- & ---- & 0.83 \\
\hline 29 & 9.471 & Gentisic acid & 0.56 & 1.17 & 1.05 \\
\hline 30 & 9.575 & L- $\alpha$-Terpineol & ----- & ----- & 0.65 \\
\hline 31 & 9.715 & Methyl 4-hydroxybenzoate & ---- & 1.36 & 0.27 \\
\hline 32 & 10.238 & a-Himachalene & 0.63 & 21.73 & 0.45 \\
\hline 33 & 10.775 & p-Cymen-7-ol & --- & 1.93 & 0.87 \\
\hline 34 & 11.126 & Phloroglucinol & 0.47 & 1.07 & 0.6 \\
\hline 35 & 11.429 & Mandelic acid, 3,4-dihydroxy & 0.32 & ----- & 0.44 \\
\hline 36 & 11.869 & Caryophyllene & 1.06 & 1.89 & 0.45 \\
\hline 37 & 11.997 & Chamigrene & ---- & ---- & 0.29 \\
\hline 38 & 12.156 & Cumaldehyde & 0.45 & ---- & 0.92 \\
\hline 39 & 12.300 & Hexa-hydro-farnesol & 0.55 & 0.45 & 3.22 \\
\hline 40 & 12.486 & Longipinene & 0.40 & 0.93 & 0.83 \\
\hline 41 & 12.608 & Benzoic acid, 4-amino & 0.57 & 1.98 & 1.1 \\
\hline 42 & 12.999 & a-Muurolene & 0.45 & 1.52 & 0.81 \\
\hline 43 & 13.500 & a-Guaiene & ---- & ----- & 1.03 \\
\hline 44 & 13.506 & 4-epi-cubedol & 0.43 & 1.14 & 0.53 \\
\hline 45 & 13.768 & Dihydrocurcumene & ----- & ---- & 0.37 \\
\hline 46 & 13.891 & $\beta$-Resorcylic acid & 0.52 & 0.42 & 0.89 \\
\hline 47 & 13.970 & 3,5-di-t-Butyl-4-hydroxybenzyl ether & -- & 0.27 & 0.89 \\
\hline 48 & 14.034 & 2,4-Di-tert-butylphenyl benzoate & --- & 0.47 & 0.67 \\
\hline 49 & 14.361 & 24,25-Dihydroxyvitamin D3 & 0.65 & ---- & 0.66 \\
\hline 50 & 14.495 & a-Cedrene & --- & ---- & 0.81 \\
\hline 51 & 14.728 & Syringic acid & --- & 0.76 & 0.57 \\
\hline 52 & 14.932 & Phytol & 0.94 & 0.33 & 0.43 \\
\hline 53 & 15.015 & Chromone, 5-hydroxy-6,7,8-trimethoxy-2,3-dimethyl- & 0.57 & 0.29 & 0.63 \\
\hline 54 & 15.213 & a-Dicarvelone & 1.02 & 0.24 & 1.28 \\
\hline 55 & 15.296 & 2',6'-Dihydroxyacetophenone & 1.13 & 0.37 & 0.62 \\
\hline 56 & 15.448 & Nopol & --- & 3.6 & 1.41 \\
\hline
\end{tabular}


Table 6. Cont.

\begin{tabular}{|c|c|c|c|c|c|}
\hline No & RT & Compound & $\begin{array}{c}\text { Raw } \\
\text { seeds }\end{array}$ & $\begin{array}{c}\text { Tap } \\
\text { water }\end{array}$ & $\begin{array}{c}\text { Saline } \\
\text { water }\end{array}$ \\
\hline 57 & 15.633 & Cyanidincation & 0.55 & 0.33 & 0.46 \\
\hline 58 & 15.842 & Ascorbic acid, permethyl- & 0.67 & 0.27 & 0.86 \\
\hline 59 & 16.020 & 2,4-Di-tert-butyl-6-(tert-butylamino)phenol & 1.05 & 6.58 & 0.62 \\
\hline 60 & 16.821 & Resorcinol & --- & 3.48 & 0.47 \\
\hline 61 & 16.867 & Isolongifolol & 1.9 & 0.79 & 0.99 \\
\hline 62 & 17.037 & Patchoulol & 0.80 & 1.20 & 1.15 \\
\hline 63 & 17.062 & Kampferol-3,4'-dimethyl ether & 1.11 & 0.68 & 0.68 \\
\hline 64 & 17.303 & Quercetin 3',4',7-trimethyl ether & 0.55 & 0.39 & 1.25 \\
\hline 65 & 17.521 & Levallorphan & --- & --- & 1.38 \\
\hline 66 & 18.781 & Propyl gallate & --- & --- & 1 \\
\hline 67 & 20.198 & Resveratrol & 2.88 & 0.45 & 0.53 \\
\hline 68 & 20.821 & Isoorientin & --- & 0.55 & 1.11 \\
\hline 69 & 21.429 & Vanylglycol & --- & 0.92 & 1.5 \\
\hline 70 & 22.480 & Phenol, 4-tert-butyl & 2.41 & 0.50 & 1.88 \\
\hline 71 & 24.109 & 4-tert-Pentylphenol & 1.25 & 0.65 & 3.17 \\
\hline 72 & 6.304 & 3-Hydroxypyridine & 0.67 & ---- & --- \\
\hline 73 & 9.874 & m-Hydroxybenzoic acid & 0.53 & ----- & ----- \\
\hline 74 & 10.711 & a-Curcumene & 1.25 & ----- & ----- \\
\hline 75 & 13.28 & $\beta$-Cubebene & 0.81 & ---- & ------ \\
\hline 76 & 13.356 & Y-Gurjunene & 0.93 & ------- & ------ \\
\hline 77 & 14.211 & Nerolidol & 0.45 & ------ & ----- \\
\hline 78 & 14.503 & Quinoline, 2-methyl- & 0.70 & ------ & --- \\
\hline 79 & 21.059 & 3-Methylkempferol & 1.72 & ----- & ------ \\
\hline 80 & 23.091 & 3,5-di-t-Butylcatechol & 2.10 & ---- & ---- \\
\hline 81 & 23.558 & 3,4',5,6'-tetra-tert-butylbiphenyl-2,3'-diol & 3.57 & ---- & ----- \\
\hline 82 & 9.364 & endo-Borneol & ---- & 1.65 & ----- \\
\hline
\end{tabular}

\section{CONCLUSION}

This study show that there was slightly increasing in protein, amino-acids and some minerals in sprouts using tap water and saline water. Whereas, there was a marked increasing in antioxidant activity, total phenols and total flavonoids in tap water and saline water sprouts.

Plants physiology changes and these dynamic changes in metabolites during sprouting process induce organic compounds as flavonoids, organic acids and phenolic compounds with significant antioxidant properties to increase in sprouting Faba bean seed irrigated either by tap water or saline water. The raise content of bioactive compounds causes that consumption of sprouts strengthens body's immunity. Therefore, accumulation of these secondary metabolites in plants provides health benefit foods.

\section{REFERENCES}

Ahmad S. and Pathak D. 2000. Nutritional changes in soybean during germination. J. of Food Sci. and Technology, 37(6), 665-666.

Akalla C. and Ersen B. 1999. Improved method for simultaneous determination of ascorbic acid and dehydroascorbic acid, isoascorbic acid and 

antioxidant properties

dehydroisoascorbic acid in food and biological samples. J. of Chromatography B: Biomedical Sci. and Applications, 730(1), 101-111.

AOAC 2012. Official Methods of Analysis of the Association of Official Analytical Chemists $19^{\text {th }}$ ed., 10 p.

Bau H.M., Villanme C., Nicolos J.P. and Mejean L. 1997. Effect of germination on chemical composition, biochemical constitutes and antinutritional factors of soy bean (Glycine max) seeds. J. of the Sci. of Food Agric., 73, 1-9.

Chen L.H. and Thacker R. 1978. Germination and nitrogenous constituents of pea seeds (Pisum sativum). J. of Food Sci., 43, 1884-1885.

Chinma C.E. and Igyor M.A. 2007. Micronutrients and anti-nutritional contents of selected tropical vegetable grown in South East. Nigeria. Nig. Food J. 25, 111-116.

Dagnia S.G., Petterson D.S., Bell R.R. and Flanagan F.V. 1992. Germination alters the chemical composition and protein quality of lupine seeds. J. Sci. Food Agric., 60, 419-423.

Kavas A. and Nehir S. 1992. Changes in nutritive value of lentils and mung beans during germination. Chem. Mikrobiol Technol. Lebensm 14, 3-9.

Kuo Y.H., Rozan P., Lambein F., Frias J. and Vidal-Valverde C. 2004. Effects of different germination conditions on the contents of free protein and non-protein amino acids of commercial legumes. J. Food Chem., 86, 537-545.

Li L., Liu B. and Zheng X. 2011. Bioactive ingredients in adzuki bean sprouts. J. Med. Plants Res., 5(24), 5894-5898.

Lopez-Amoros, M.L., Hernandez and Estrella T. 2006. Effect of germination on legume phenolic compounds and their antioxidant activity. J. Food Comp. Anal., 19, 277-283.

Mostafa M.M., Rahma E.H. and Rady A.H. 1987. Chemical and nutritional changes in soybean during germination. Food Chem., 23, 257-275.

Okumura K., Hosoya T., Kawarazaki K., Izawa N. and Kumazawa S. 2016. Antioxidant Activity of Phenolic Compounds from Fava bean Sprouts. J. of Food Sci., 81(6), 1394-1398.

Prieto P., Pineda M. and Aguilar M. 1999. Spectrophotometric quantitation of antioxidant capacity through the formation of a phosphomoIybdenum complex: specific application to the determination of vitamin E. Anl. Biochem., 1; 269(2), 337-341.
Randhir R., Lin Y.T. and Shetty K. 2004. Stimulation of phenolics, antioxidant and antimicrobial activities in dark germinated mung bean sprouts in response to peptide and phytochemical elicitors. Process Biochem., 39, 637647.

Rodriguez C., Frias J., Vidal-Valverde C. and Hernandez A. 2008. Correlations between some nitrogen fractions lysine, histidine, tyrosine and ornithine contents during the germination of peas, beans and lentils. Food Chem., 108, 245-252.

Santana P.M., Miranda M., Payrol J.A., Silva M., Hernández V. and Peralta E. 2013. Gas Chromatography-Mass Spectrometry Study from the Leaves Fractions Obtained of Vernonanthura patens (Kunth) H. Rob. Int. J. of Organic Chemistry, 3, 105-109.

Snedecor G.W. and Cochran W.G. 1980. Statisical methods, $7^{\text {th }}$ Ed., lowa State Univ. Press, Ames lowa, USA.

Tahany A.A. 2015. Biochemical studies of antidiabtiec effect of some seed sprouts in adult male albino rats. ph. D. Thesis Dept. of Biochemistry, Fac. Of Agric. Cairo Univ., Egypt $196 \mathrm{p}$.

Vijayakumari P., Siddhuraju P., Pugalenthi M. and Janardhanan K. 1998. Effect of soaking and heat processing on the levels of antinutrients and digestible proteins in seeds of Vigna sinensis. Food Chemistry, 63, 259-264.

Xue Z., Wang C., Zhai L., Yu W., Chang H., Kou X. and Zhou F. 2016. Bioactive Compounds and Antioxidant Activity of Mung Bean (Vigna radiata L.), Soybean (Glycine max L.) and Black Bean (Phaseolus vulgaris L.) during the Germination Process. Czech J. Food Sci., 34(1), 68-78.

Yuwei L. and Weihua X. 2014. Effect of soaking and sprouting on iron and zinc availability in green and white Faba bean (Vicia faba L.). J. List J. Food Sci. Technology 51(12), 39703976.

Zoltek U., Szymanowska U., Baraniak B. and Karaś M. 2015. Antioxidant activity of polyphenols of adzuki bean (vigna angularis) germinated in abiotic stress Conditions. Acta. Sci. Pol. Technol. Aliment 14(1), 55-62. 


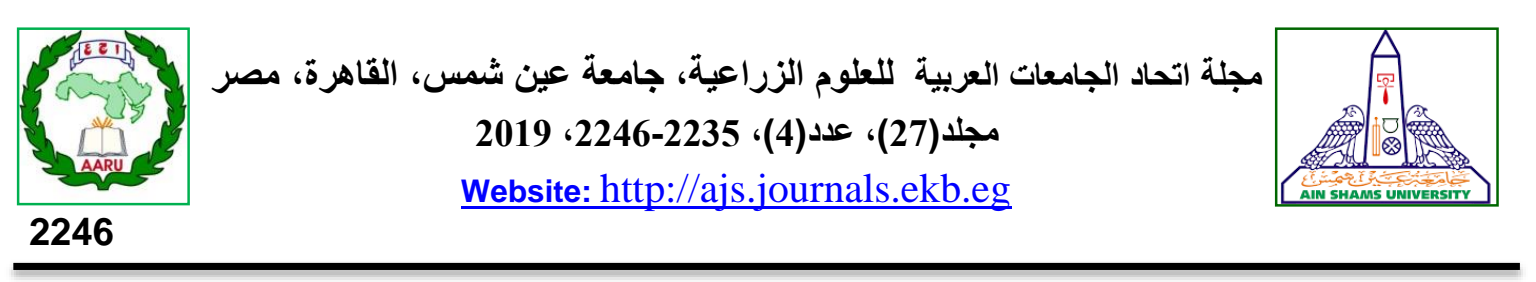

تأثير عملية الانبات بإستخدام الماء المملح على خصائص بذور الفول البلدى

[178]

$$
\begin{aligned}
& \text { علاء محمد حجازى1" - نشوى عطية أبو العزم2 } 2 \text { - محمد حسنين أمين الجمال } 1 \text { ـ } \\
& \text { ممدوح محمد فوزي عبد اللها }
\end{aligned}
$$

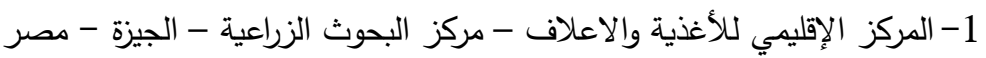

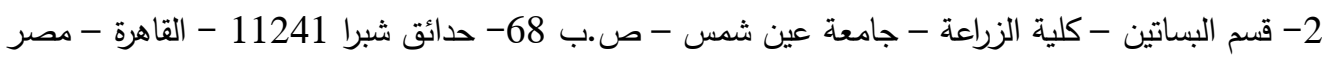

*Corresponding author: www.am7626019@gamil.com

Received 14 July, 2019 Accepted 22 October, 2019

وقد أظهرت هذه الدراسة أن هناك زيادة في نسبة

البروتين والأحماض الأمينية وبعض العضاض العناصر المعدنية

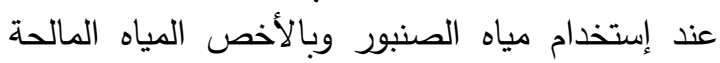

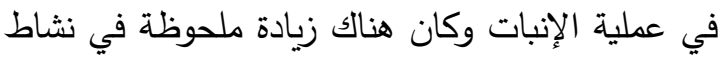

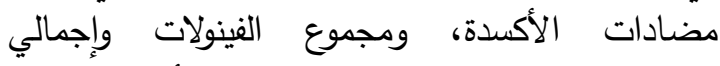
الفلافونويدات في ماء الصكدة الصنبور وبات الأخص المبات المياه

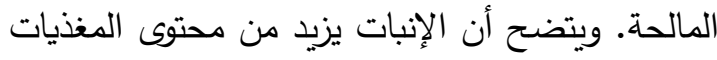

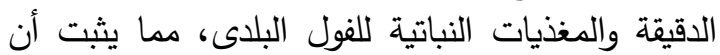

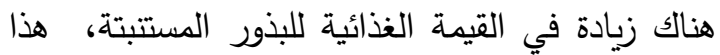
بالإضافة إلى أن الإنبات هو الفيمة وسيلة جيدة لتعزيز

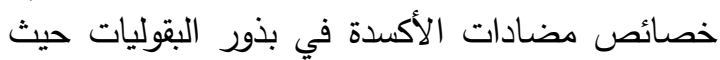

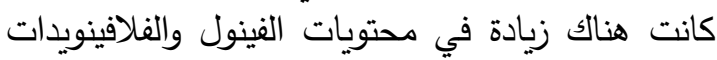
في نبت حبوب الفول البلدى خاصة مع استخدام تركيز

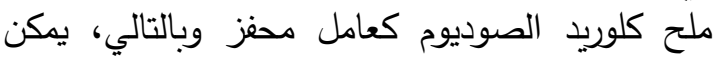

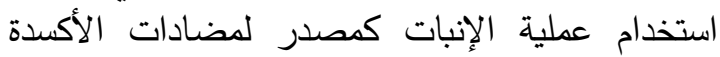

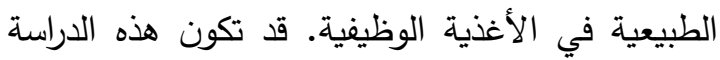

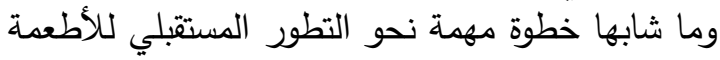

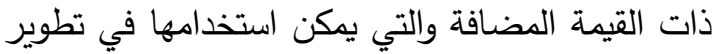

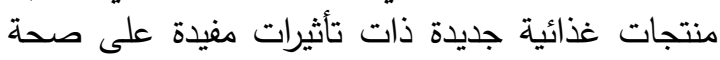

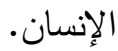

الكلمات الدالة: الإنبات، الماء المملح، خصائص بذور

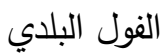

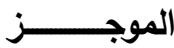

تلعب البقوليات دورًا مهمًا في تغذية الإنسان في العيات العديد من البلدان. الانبات هي واحدة من العمليات

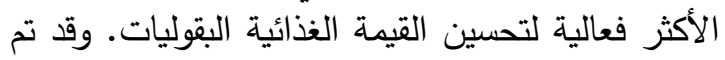
اختيار بذور الفول البلدى صنف سخا 4 لهذه الدراسة.

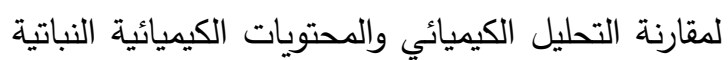

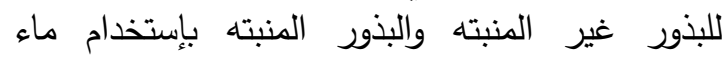
الصنبور والمياه المالحة بتركيزات مختلفة (10002000-3000-4000 جزء فى المليون). بالإضافة إلى ذلك، مقارنة نشاط مضادات الأكسدة (مجموع بالإنات الإنات

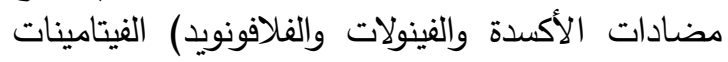
بعض المركبات الاخرى التى غالبا مايتغيرتركيبها وتركيزها بشكل كبير أثناء عملية الإنبات.

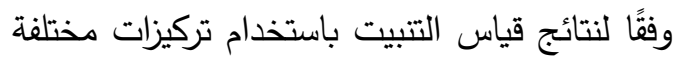

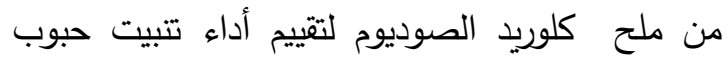

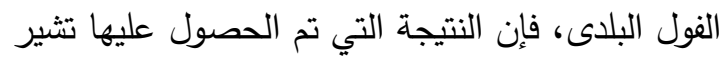

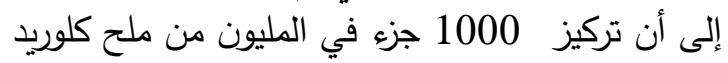

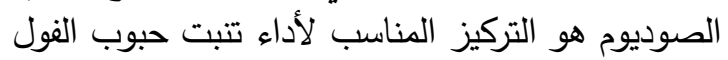

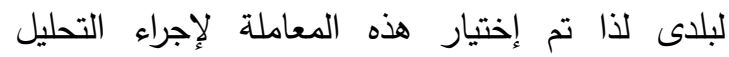
الكيميائي وللتعرف على المركبات الكيميائية النباتية

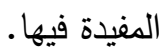

$$
\text { تحكيم: ا.د نظمي عبدالحميد } 1.1 \text { محمود عبدالله صالح }
$$


